\section{Hemmet enzym- aktivitet ved kronisk utmattelsessyndrom?}

Pasienter med kronisk utmattelsessyndrom har svekket enzymfunksjon relatert til energiomsetningen, ifølge en studie ved Haukeland universitetssykehus.

Tidligere studier har vist at pasienter med kronisk utmattelsessyndrom, ofte kalt ME/ $\mathrm{CSF}$, har senket nivå av enkelte aminosyrer i serum. Forskningsmiljøer ved Haukeland universitetssykehus har nylig publisert en studie der serum fra 200 pasienter og 100 kontrollpersoner ble undersøkt (1). Pasientene ble utredet for kronisk utmattelsessyndrom i henhold til de kanadiske kriteriene for sykdommen. Nivåene av de 20 aminosyrene ble undersøkt med massespektometri, der man fant en spesifikk nedgang av aminosyrer hos kvinner. Disse aminosyrene tilhører en gruppe som brytes ned uavhengig av enzymet pyruvatdehydrogenase (PDH). I de hvite blodcellene ble mRNAnivået for ulike regulerende faktorer for dette enzymet undersøkt, og der fant man oppregulert uttrykk av faktorer som virker hemmende på enzymfunksjonen. Disse endringene var til stede i begge kjønn.

- Funksjonell pyruvatdehydrogenase er en av de viktigste faktorene for velfungerende mitokondrier, sier Zhenhe Suo, førsteamanuensis ved Avdeling for patologi ved Universitetet i Oslo.

- Velfungerende mitokondrier vil sørge for normal funksjon av celler og organer. Funnet av unormal energiomsetning ved kronisk utmattelsessyndrom kan forklare flere av de kliniske metabolske manifestasjonene ved sykdommen, sier Suo.

Funnene støttes også av in vitro-studier der pyruvatdehydrogenase er inaktivert med såkalt knockoutgenteknologi (2). - Når pyruvatdehydrogenase blir inaktivert, blir cellene tvunget til aerob glykoslyse, slik at de produserer mindre energi, men gir overskudd av laktat. Disse studiene har nye funn som fremhever den funksjonen pyruvatdehydrogenase har i sykdomsutviklingen ved kronisk utmattelsessyndrom, sier Suo.

\section{Ruth Halsne}

Tidsskriftet

\footnotetext{
Litteratur
1. Fluge $\emptyset$. Mella O, Bruland 0 et al. Metabolic profiling indicates impaired pyruvate dehydrogenase function in myalgic encephalopathy/chronic fatigue syndrome. JCl Insight 2016; 1: e89376.

2. Li Y, Li X, LiX et al. PDHA1 gene knockout in prostate cancer cells results in metabolic reprogramming towards greater glutamine dependence. Oncotarget 2016; 7: 53837-52.
}

\title{
Genetisk markør på resistens ved malaria
}

\author{
Ved å genteste Plasmodium falciparum-stammer kan man påvise muta- \\ sjoner assosiert med behandlingsresistens ved malaria.
}

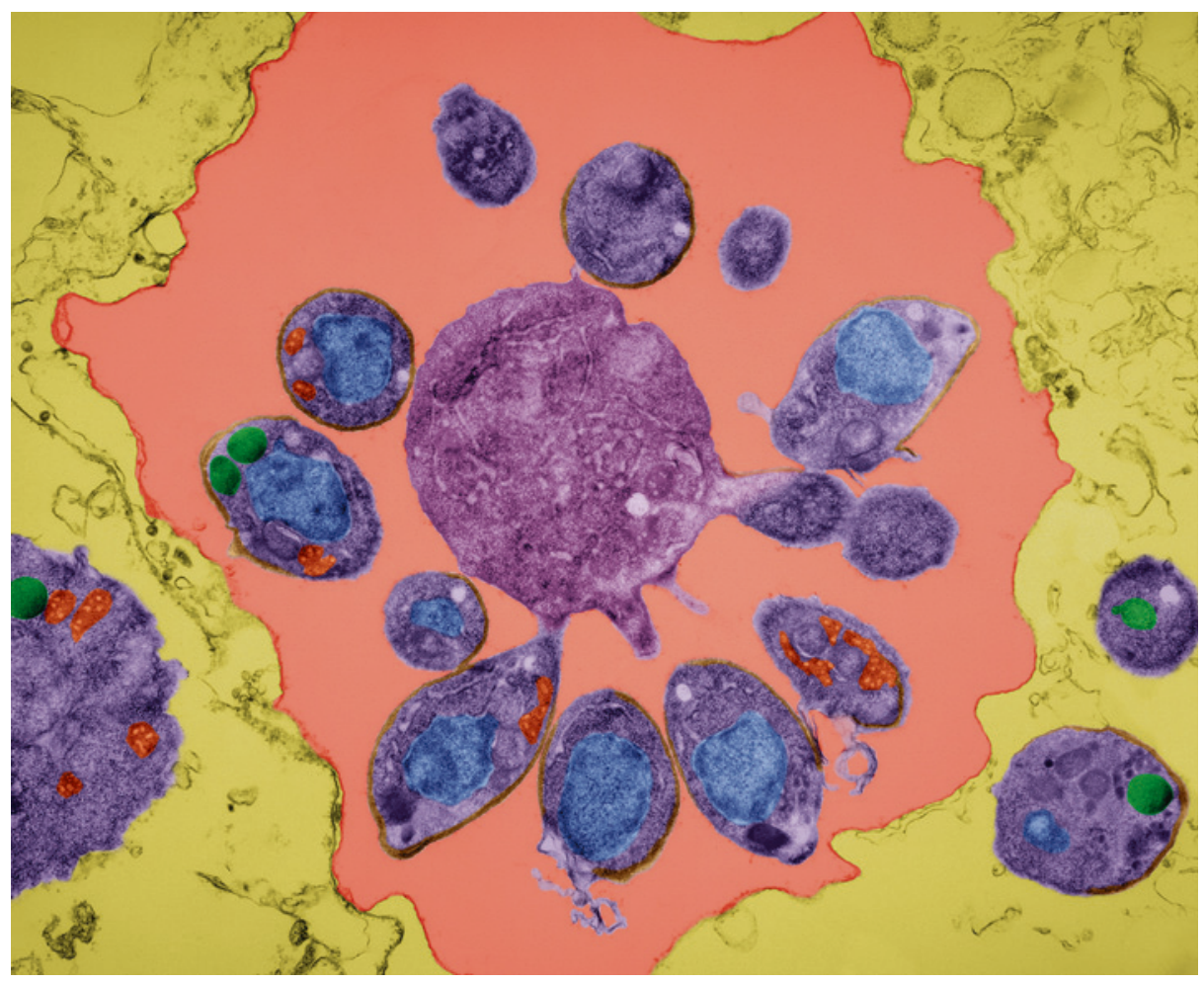

Plasmodium falciparum. Foto: Science Photo Library

Kombinasjonspreparater med artemisinin og et annet antimalariamiddel er vanligvis førstevalg ved behandling av ukomplisert malaria forårsaket av $P$. falciparum i endemiske områder, men resistensutvikling mot disse preparatene er et $\varnothing$ kende problem. Bedre og mer presis monitorering av resistensmønstre vil kunne hindre resistente malariastammer i å få økt utbredelse.

I Sørøst-Asia er kombinasjonspreparat med artemisinin og piperakin førstevalg, men behandlingssvikt ved slik behandling er blitt vanligere i regionen. To studier fra Kambodsja ble utført med mål om å finne molekylære markører for resistens mot piperakin gjennom helgenomanalyser av $P$. falciparum, og begge viste at amplifisering av en spesiell region, plasmepsin 2-3, var en sterk markør for resistens $(1,2)$. Forekomsten av denne genvarianten økte fra 2002 til 2015, parallelt med økende hyppighet av klinisk behandlingssvikt. I en av studiene ble det også påvist en annen genmarkør for resistens, kalt exoE415G (2).

Forfatterne av begge studiene foreslår at monitorering av forekomsten av de påviste genvariantene bør tas i bruk, slik at behandlingstiltak mot malaria kan ta hensyn til regional utbredelse av resistente $P$. falciparum-stammer.

\section{Kristoffer Brodwall}

kristoffer.brodwall@gmail.com

Barne- og ungdomsklinikken

Haukeland universitetssykehus

\section{Litteratur}

1. Witkowski B, Duru V, Khim N et al. A surrogate marker of piperaquine-resistant Plasmodium falciparum malaria: a phenotype-genotype association study. Lancet Infect Dis 2017; 17: 174-83.

2. Amato R, Lim P, Miotto $\mathrm{O}$ et al. Genetic markers associated with dihydroartemisinin-piperaquine failure in Plasmodium falciparum malaria in Cambodia: a genotype-phenotype association study. Lancet Infect Dis 2017; 17: 164-73. 